\title{
Melanoniquia longitudinal inducida por hidroxiurea en policitemia vera
}

Hydroxyurea-induced longitudinal melanonychia in polycythemia vera

\section{CASE REPORT}

A Caucasian 79-year-old female was referred to the Internal Medicine Consultation for etiologic investigation of erythrocytosis (haemoglobin $20.5 \mathrm{~g} / \mathrm{dL}$, hematocrit $62 \%$ ) and segmental pulmonary thromboembolism. Her past medical history included arterial hypertension, dyslipidemia and obesity. After the complementary study carried out, the diagnosis of polycythemia vera was made (heterozygous V617F mutation in the JAK2 gene). The patient was then referred to the Hematology Consultation and started hydroxyurea (initially 500mg twice daily), along with phlebotomies. She was already under systemic anticoagulation. The patient had a good response, with hematocrit control.

After 5 months of beginning with hydroxyurea, she developed asymptomatic and progressive longitudinal dark brown bands involving all her fingernails (Figure 1) and toenails (Figure 2). The bands were well-defined and with different widths. In some fingernails, the pigmentation bands spread proximally underneath the translucent cuticles, but the nail folds were not affected (PseudoHutchinson's sign). There was no nail thickening or atrophy. No history of trauma and there was no history of melanoma in her family. It was assumed drug-induced longitudinal melanonychia due to hydroxyurea. No other side effects of the drug were seen, so it was decided to maintain the drug due to the risk of another thrombotic event with the suspension.

Hydroxyurea is a cytostatic drug typically used for the treatment of myeloproliferative disorders and is generally a well-tolerated drug ${ }^{1}$. Melanonychia is a rare side effect of this drug that occurs only in $4.3 \%$ of the patients ${ }^{2}$. Besides, the involvement of all 20 nails is even rarer and only five cases were reported ${ }^{1,2,3,4}$. The time between the initiation of hydroxyurea and the onset of the melanonychia varies from 4 weeks to 5 years ${ }^{5}$. Other differential diagnoses should be considered such as physiological causes, repetitive trauma, onychomycosis or underlying systemic disease ${ }^{5}$. In the case of a single affected nail, subungual melanoma should be ruled out, especially in the presence of the Hutchinson's sign (nail pigmentation affecting also the cuticle and nail fold) ${ }^{6}$. So, this drug side effect should be known to avoid misdiagnosis. After discontinuation of hydroxyurea, melanonychia generally disappears as the nail grows. However, the decision to stop therapy needs to be pondered because of the risk of thrombotic events. If no more serious cutaneous effects occur, we think the drug should not be discontinuing.

\section{REFERENCES}

Figure 1

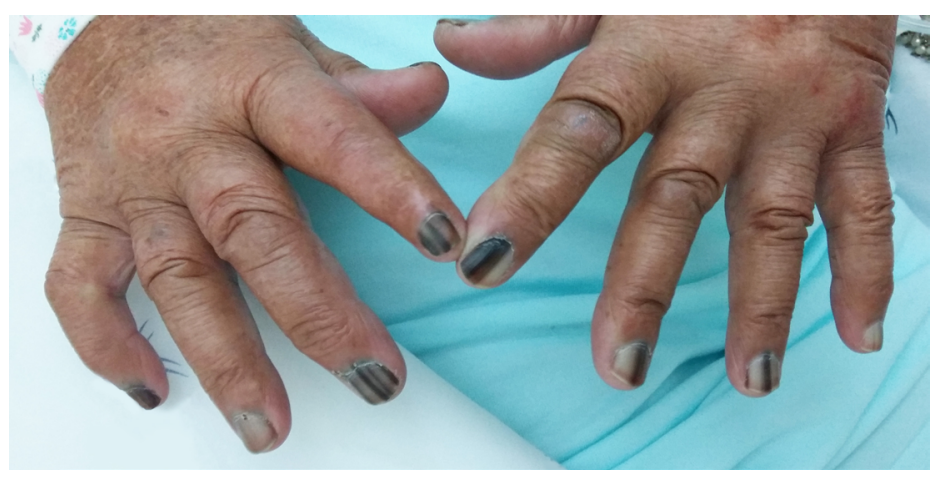

Figure 2

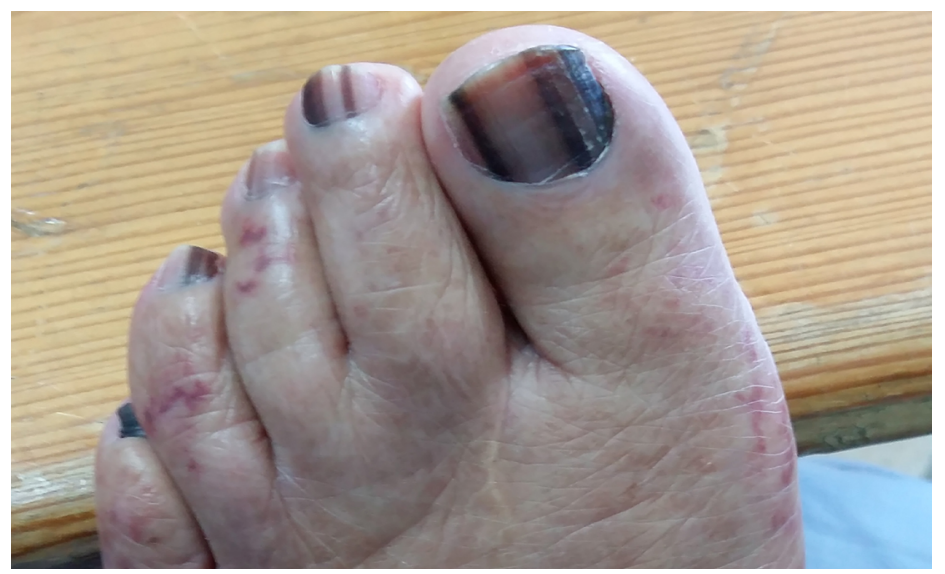

1. França ER, Teixeira MA, Matias Kde F, Antunes DE, Braz Rde A, Silva CE. Cutaneous effects after prolongaded use of hydroxyurea in Polycythemia Vera. An Bras Dermatol. 2011;86(4):751-754.

2. Aste N, Fumo G, Contu F, Aste N, Biggio P. Nail pigmentation caused by hydroxyurea: report of 9 cases. J Am Acad Dermatol. 2002;47(1):146-147

3. Karanth SS, Gupta A, Prabhu M. Melanonychia and mucocutaneous hyperpigmentation from hydroxyurea use for the treatment of essential thrombocytosis. Singapore Med J. 2014;55(1):e7-e8.

4. Murray NP, Tapia P, Porcell J, Echavarria M, Suazo H. Acquired melanonychia in chilean patients with essential thrombocythemia treated with hydroxyurea: a report of 7 clinical cases and review of the literature. ISRN Dermatol. 2013;2013:325246.

5. Nguyen AL, Körver JE, Theunissen CC. Longitudinal melanonychia on multiple nails induced by hydroxyurea. BMJ Case Rep. 2017;2017:bcr2016218644.

6. Baran R, Kechijian P. Hutchinson's sign: a reappraisal. J Am Acad Dermatol. 1996;34(1):87-90.

Palabras clave: enfermedades de las uñas, hidroxiurea, policitemia vera.

Keywords: nail diseases, hydroxyurea, polycythemia vera.

\section{Susana Marques de Sousa, Marta Rafael Marques}

Serviço de Medicina Interna. Centro Hospitalar Póvoa de Varzim, Vila do Conde

Correspondencia: susana.m.sousa.g@gmail.com

Cómo citar este artículo: Marques de Sousa S, Rafael Marques M

Melanoniquia longitudinal inducida por hidroxiurea en policitemia vera. Galicia Clin 2021; 82-1: 58

Recibido: 20/9/2019; Aceptado: 15/10/2019 // https://doi.org/10.22546/60/2089 